the Crag at Thorpe, near Norwich; and in 1840 he sent to the "Magazine of Natural History" a "Notice of the existence of a distinct Tube within the hollows of the Paramoudra." In later years he announced before the Norwich Geological Society, the finding of Deer's antlers in the re-deposited Chalk at Hartford Bridges, near Norwich; and also the discovery of Flint Implements in the valley of the Little Ouse. His fine collection is placed in a special room in the new Museum-buildings at Norwich Castle. He died on April 4th, 1895, in the 93rd year of his age.

\title{
JOHN ELLOR TAYLOR, PH.D., F.L.S., ETC.
}

Born September 21st, 1835.

Died Septemer 28th, 1895.

As an enthusiastic lover of Nature, and a popular exponent of Geological and Botanical Science, Dr. Taylor did much to arouse in others an interest in Natural History subjects. The son of the foreman of a cotton factory, he was born at Levenshulme, Manchester, and was employed in early years in the railway-works at Crewe. Developing a taste for literature and science, he read largely, cultivated a facile style of writing, and became a contributor to a Manchester paper. His leisure hours were devoted to Geology, and in his first work, "Geological Essays" (1864), he gave a sketch of the geology of Manchester and its neighbourhood. About the year 1862 he settled in Norwich, as a sub-editor of the Norwich Mercury, and stirred up much interest in the geolngy of the country round the old city. He drew attention to the disturbed Chalk at Whitlingham, Swainsthorpe, and other places; he pointed out the differences in the Mollusca preserved in the two shell-beds in the Norwich Crag at Bramerton; and, in conjunction with the late John Gunn, he established the Norwich Geological Society, which is now incorporated with the Norfolk Naturalists' Society. Before these local Societies, and before the British Association, the results of his geological observations were brought; and records of his work are printed in the earlier volumes of the Geologrcal Magazinf. In 1866 he published a little irtroduction to Geology, entitled "Lithographs," and subsequently other popular works on Natural History flowed from lis pen. In 1872 he was appointed Curator to the Ipswich Museum, a post from which he retired through ill-health about two years ago. He contributed a capital "Sketch of the Geology of Suffolk" to White's History of the County ; and for many years he was Editor of Science Gossip. His Science Lectures at Ipswich and elsewhere were widely appreciated, and of late years he was a strong advocate of the search for Coal in East Anglia.

Dr. J. E. Taylor was present in the Geological Section of the British Association at Ipswich in September Jast, and spoke on the subject of the deep-boring in search of coal at Stutton; and definitely stated his opinion, that though unfavourable to the anticipations and hopes of himself and others, he believed that the boring had brought up a sample of the Yoredale Shales below the real Coal-measures.

Erratum.-On p. 472, October Number Geol. Mag., line 17 from top of page, for Geniformes read Gruifornes.-Emit. Geol. Mag. 